\title{
Analysis of Potential Sectors and Policy Priorities of Regional Economic Development in Maluku
}

\author{
Bayu Kharisma', Ferry Hadiyanto²
}

\begin{abstract}
The development policy in Maluku Province cannot separate from the small islands that dominate the areas. Its central potentials are in the field of fisheries, agriculture, and mining. This research aims to analyze the potentials of the leading sector and to formulate policy priorities for regional development in Maluku Province. The research used in this research is Location Quotient (LQ), Growth-Ratio Model (MRP), Overlay, SWOT and Analytic Network Process (ANP). The results showed that in Maluku Province there are eight economic categories that have base sectors. The result of Growth-Ratio Model (MRP) shows that the sector with the highest average the ratio of growth in the study area $\left(R P_{S}\right)$ is mining and quarrying sector. Furthermore, Overlay analysis shows that government administration, defense, social security sectors are obliged to contribute to and the highest growth. The result of SWOT-ANP shows that policy priority in regional development is the acceleration of infrastructure development.
\end{abstract}

Keywords: regional economic development, leading sector, policy priorities

JEL Classification: E01, H70, R11

\begin{abstract}
Abstrak. Kebijakan pembangunan di Provinsi Maluku tidak bisa dipisahkan dari wilayah yang didominasi oleh pulau-pulau kecil dengan potensi utama di bidang perikanan, pertanian dan pertambangan Penelitian ini bertujuan untuk menganalisa potensi-potensi sektor unggulan dan menyusun prioritas kebijakan untuk pengembangan wilayah di Provinsi Maluku. Metodologi penelitian yang digunakan adalah Location Quotient (LQ), Model Rasio Pertumbuhan (MRP), Overlay, SWOT dan Analytic Network Procecss (ANP). Hasil penelitian menunjukkan bahwa di Provinsi Maluku terdapat 8 kategori ekonomi yang memiliki sektor basis. Hasil perhitungan model rasio pertumbuhan (MRP) menunjukkan bahwa sektor yang memiliki nilai rata-rata pertumbuhan regional (RPs) tertinggi yakni sektor pertambangan dan penggalian. Selanjutnya, analisis Overlay menunjukkan bahwa sektor administrasi pemerintahan, pertahanan, jaminan sosial wajib memberikan kontribusi dan pertumbuhan tertinggi. Hasil analisis SWOT-ANP menunjukkan bahwa prioritas kebijakan dalam pengembangan wilayah adalah percepatan pembangunan infrastruktur.
\end{abstract}

Kata Kunci: pembangunan ekonomi regional, sektor unggulan, prioritas kebijakan

\section{How to Cite:}

Kharisma, B., \& Hadiyanto, F. (2019). Analysis of Potential Sectors and Policy Priorities of Regional Economic Development in Maluku. Etikonomi: Jurnal Ekonomi. Vol. 18 (1): 29 - 46. doi: http//dx.doi.org/10.15408/etk. v18i1.7440. 


\section{Introduction}

The concept of the region as a new policy approach in regional development has been increasingly widely used in various countries, both developed and developing countries, including in Maluku province especially concerning the readiness of a region to increase its competitiveness in facing regionalization and globalization. The development policy in Maluku Province cannot separate from the small islands that dominate the areas. Its central potentials are in the field of fisheries, agriculture, and mining. The problems of small island development are always related to conflicts between the environment and economic activity. Therefore, the ecological vulnerability of small islands will significantly affect the development process. Degradation of ecosystems will cause problems to the surrounding environment. Consequently, it is necessary to formulate policies to deal with economic pressures while also maintaining the integrity of the natural resources for sustainable development.

Maluku Province consists of many small islands. Thus connectivity between marine fisheries development and tourism should be the leading developed sector and priority program. Therefore, the infrastructure development program, from the construction of road infrastructure, bridges, ports, to the airport is expected to minimize transaction costs and indirectly move the economy more evenly to all regions in Maluku. Meanwhile, the development of the tourism sector is expected to have a positive impact on economic performance and community welfare in Maluku Province as it provides jobs enabling people to earn income.

However, the development of marine fisheries and tourism supported by infrastructure will not be effective if it is not supported with skilled human resources in Maluku Province, mainly if it is associate with the fast-growing oil and gas sector in Masela Block. Therefore, the existence of skilled human resources is needed, both through vocational education and training so Maluku Province can have a skilled and competitive workforce. Also, skilled workforce is dependent on a better level of health. Thus, the improvement of health facilities is significant as proper health can increase the economic productivity of the Maluku people.

Afterward, in 2017, the Gross Regional Domestic Revenue (PDRB) in Maluku province from the demand side is supported by the high level of household consumption. The high household consumption influenced by the increase of income through the provision of Hari Raya Allowances (THR) for civil servants and private employees in June 2017. Revenue also increased in line with the strengthening of Farmers Exchange Rate (NTP) as the acceptance index (Indeks Terima) obtained by farmers is better than the Pay Index (Indeks Bayar) issued by farmers. Farmer's Term of Trade Indices strengthening also occurs in Farmer's Term of Trade Indices food material, Farmer's Term of Trade Indices plantations, and Farmer's Term of Trade Indices livestock. Thus, these things encourage higher consumption, especially during the Idul Fitri holiday that coincides with school children's holidays.

Meanwhile, PDRB from the industrial origin, agricultural performance, forestry and fishery as one of the main categories grew slowly. The slow growth is due to the slow performance of fisheries as extreme weather hamper fishing activities. However, for the foreseeable future, the agriculture and fisheries sector is expected to grow considerably, in 
line with the improving weather that can increase the productivity of fisheries. The main contributing sectors are agriculture, forestry, and fisheries, from 5.2 trillion in 2012 to around 6.2 trillion in 2016. However, the growth rate fluctuates with 2012 having a growth of 6.23 percent, but decreasing to 4.82 in 2016. For those five years, growth in 2012 is the highest with the lowest in 2015 , which is only at 1.25 percent. (See detail in Table 1).

Table 1. Gross Domestic Product at Constant Market Prices By Industrial Origin (Billion Rupiahs), 2012-2016

\begin{tabular}{|c|c|c|c|c|c|c|}
\hline & Industrial Origin & 2012 & 2013 & 2014 & 2015 & 2016 \\
\hline A & $\begin{array}{l}\text { Agriculture, Livestock, Forestry } \\
\text { and Fishery }\end{array}$ & $5.282,61$ & $5.500,92$ & $5.835,44$ & $5.908,22$ & $6.192,71$ \\
\hline B & Mining and Quarrying & 663,46 & 674,43 & 819,22 & 811,27 & 842,97 \\
\hline C & Manufacturing Industry & $1.121,18$ & $1.186,17$ & $1.286,06$ & $1.336,32$ & $1.430,36$ \\
\hline D & Electricity, Gas \& Water Supply & 18,03 & 18,72 & 25,65 & 26,99 & 29,24 \\
\hline $\mathrm{E}$ & $\begin{array}{l}\text { Water Supply, Waste } \\
\text { Management and Recycling }\end{array}$ & 109,01 & 112,26 & 118,82 & 119,48 & 124,34 \\
\hline $\mathrm{F}$ & Construction & $1.403,27$ & $1.511,83$ & $1.622,35$ & $1.712,13$ & $1.797,42$ \\
\hline G & $\begin{array}{l}\text { Wholesales, Retail, Car Repair, } \\
\text { Motor }\end{array}$ & $2.976,30$ & $3.198,28$ & $3.327,58$ & $3.564,80$ & $3.776,00$ \\
\hline H & Transportation and Warehousing & $1.118,33$ & $1.191,63$ & $1.295,79$ & $1.361,61$ & $1.418,65$ \\
\hline I & $\begin{array}{l}\text { Provision of Accommodation } \\
\text { and Meals Drink }\end{array}$ & 373,90 & 404,59 & 423,52 & 456,30 & 455,15 \\
\hline J & Information and Communication & 766,10 & 836,24 & 899,97 & 981,13 & $1.058,79$ \\
\hline $\mathrm{K}$ & Financial Services and Insurance & 738,22 & 810,02 & 861,68 & 924,51 & $1.009,71$ \\
\hline L & Real Estate & 76,98 & 79,08 & 84,69 & 87,09 & 89,06 \\
\hline $\begin{array}{l}M, \\
N\end{array}$ & Company Services & 225,69 & 238,64 & 250,16 & 258,71 & 264,38 \\
\hline $\mathrm{O}$ & $\begin{array}{l}\text { Mandatory Administration of } \\
\text { Government, Defense and Social } \\
\text { Security }\end{array}$ & $4.116,34$ & $4.285,73$ & $4.519,31$ & $4.969,72$ & $5.298,92$ \\
\hline$P$ & Educational Services & $1.122,99$ & $1.161,96$ & $1.272,53$ & $1.372,33$ & $1.481,77$ \\
\hline Q & $\begin{array}{l}\text { Health Services and Social } \\
\text { Activities }\end{array}$ & 502,86 & 504,09 & 517,35 & 542,49 & 572,49 \\
\hline $\begin{array}{l}\mathrm{R}, \\
\mathrm{S} \\
\mathrm{T} \\
\mathrm{U}\end{array}$ & Other Services & 384,81 & 386,34 & 407,61 & 425,97 & 449,25 \\
\hline & Gross Domestic Product & $21.000,08$ & $22.100,94$ & $23.567,73$ & $24.859,06$ & $26.291,19$ \\
\hline
\end{tabular}

Source: BPS Maluku Province, 2016

The rationale for the above phenomenon is the dependency of the agricultural sector with the climate in archipelagos. Not enough infrastructure development to support the growth of agriculture sector becomes the main obstacle. The condition of land, sea and 
air transportation connecting inter-regency or municipal areas in Maluku province is still challenging to develop. Economic activity is unsuccessfully developed into an investment interest for better technology regarding on-farm and out-farm. Conventionalism still dominates the development of the agricultural sector.

Some empirical studies related to potential and leading sectors have long attracted economists and policymakers because they involve empirical results and different approaches. Setyorini \& Gunawan (2008) uses a Klassen Typology analysis, MRP, LQ, Krugman Divergence Index analysis and Connectivity Quotient (CQ) analysis to the identification of regional development of members of regional institutions of Barlingmascakeb. Gunawan (2011) analyzed the key economic sectors of Rembang Regency in 2000-2008 uses ShiftShare, MRP, Location Quotient, Overlay and forecasting. Basuki \& Gayatri (2009) uses Growth Ratio Model (MRP), Shift Share, LQ, Overlay and Klassen Typology to leading sector determinants in Ogan Komering Ilir District. Aswandi \& Kuncoro (2002) uses Klassen Tipology analysis tools, Location Quotient, Regional Specialization Index, Logic (Binary Logistic Regression), and Multinomial Logistic Regression with an empirical study of the economic position of the regions in South Kalimantan. Ariyasa (2009) researched Gianyar regency, on the identification of pre-eminent sector by using Location Quotient analysis tools, Growth Ratio Model and overlay.

One effort is to see the various potentials owned by an area. If the potential developed optimally, then it will indirectly benefit the area. Therefore, by optimizing the economic activity of potential sectors, the sector will grow and become a base sector in the region. With the increase of economic activity in the base and potential sector of the region, it will increase PDRB. Sectoral or leading subsector specialization in each region can improve community effectiveness and efficiency in carrying out economic activities. Thus, the local government must know exactly what the base sector and the non-base sector is and the potential sectors for a new base sector in the area. Therefore, looking at the various problems that occurred in Maluku Province, especially from the business or sector, the purpose of this study is to analyze the potentials of the leading sector to identify the overall form of the existing economic structure and formulate policy priorities for economic development in Maluku Province.

Combining SWOT with ANP has been conducted in only a tiny number of studies. Some studies had using SWOT-ANP to analyze the potential and prioritization strategies (Azimi et al., 2011; Arsic et al., 2018; Yüksel \& Dagdeviren, 2007). This study provides important empirical contributions or novelty among others by applying hybrid multiple criteria decision analysis (SWOT-ANP) in regional planning methodology which introduces a novel systematic approach to planning and managing the concept of regional planning in Maluku Province. Thus, this study contributes to the expansion of the methodology in the field of regional planning. Also, by the obtained results, it suggests a new approach to strategic decision-making in regional planning, especially in Maluku Province. 


\section{Methods}

In analyzing this research, it uses location quotient (LQ), growth-ratio model (MRP), overlay and SWOT-Analytic Network Process (ANP). The analysis tool aims to identify the leading sector and economic structure that exists and priorities policy in Maluku provinces.

Location Quotient (LQ) is a statistical method that uses the characteristics of output/ value added or employment opportunity to analyze and determine the diversity of the local base economy (Bendavid-Val, 1991; Arsyad, 1999). Sectors classified into the local base economy are sectors concerning income and employment. The LQ analysis provides a framework for understanding the stability and flexibility of the economy to change conditions by analyzing the degree of industry or sectors in the community (Heilbrun, 1987). The statement can formulate as follows:

$$
L Q_{i}=\frac{v_{i} / v_{t}}{v_{i} / v_{t}}
$$

Where: $L Q_{i}$ denotes the value of location quotient i sector in an area; $v_{i}$ denote the amount of output/labor of industry $i$ in an area; $v_{t}$ denotes the total amount of output/labor available in an area; $v_{i}$ denote the amount of output/labor of industry $i$ in the reference region; $v_{t}$ denote the total amount of output/labor available in the reference region

The value shown in this LQ formula explaine as follow: (i) If the value of $L_{Q}>1$ then sector $\mathrm{i}$ in the area is more specialized than the same sector in the reference region, in other words the sector is capable of exporting its products/labor (base sector); (ii) If the value of $\mathrm{LQ}_{\mathrm{i}}<1$ then sector $\mathrm{i}$ in the area is less specialized than the same sector in the reference region. In other words, the sector is unable to export its products/labor (non-base sector); (iii) If the value of $L_{i}=1$ then sector $i$ in the area has the same level of specialization compared to the same sector in the reference region. In other words, the sector can meet the needs of its region.

Location Quotient Analysis (LQ) to identify potential economic categories and subcategories based on PDRB contribution criteria, other analysis tools are essential to identify potential economic potentials. Growth Ratio Model (MRP) is also used to analyze potential economic categories and subcategories based on PDRB growth in Maluku Province. This growth ratio model is used to view the description of the economic activity, especially the economic structure of the research area, emphasizing on growth. The growth ratio model can be used to determine the sector or the leading subsector based on PDRB growth. This model of analysis uses the comparison of the growth of a sector or subsector on a small or large scale. In MRP analysis, there are two kinds of growth ratios, namely Growth Ratio of Reference Areas (RPr) and Growth Ratio of Study Areas (RPs) (Tarigan, 2005).

There are four categories in the growth ratio model, among others. First, RPs and RPr have a value (+), meaning those activities at the reference region level and the research area growth rate stands out. Second, the value of RPs (+) and $\operatorname{RPr}(-)$, means that the activity at the reference level is growing prominently and the growth at the research area is not yet 
outstanding. Third, the value of RPs (-) and $\mathrm{RPr}(+)$, means that activities at the reference level do not have a prominent growth and the growth at the research area stand out. Fourth, RPs and RPr have a value of (-), means the activity at the reference region level or the growth at the research area is not yet outstanding.

After calculating using LQ and MRP analysis, the next is to overlay the results of LQ analysis with MRP analysis. This overlay technique uses the calculation of RPs (growth) and LQ (contributions). The results of this analysis are used to develop potential economic sectors (Kuncoro, 2004).

The results of this analysis classify into four types, namely: First, RPs and LQ have a value $(+)$, indicate that the economic sector is dominant in growth and contribution. Second, RPs $(+)$ and LQ (-), indicate the economic sector is dominant in growth, but its contribution is small. Third, RPs (-) and LQ (+), indicate the economic sector has small growth but a significant contribution. Fourth, RPs and LQ have a value (-), indicate that the economic sector has a small value in both growth and contribution.

The next method that used in this research is the analytic network process. This method is a new approach to qualitative methods, further development of the previous method of Analytical Hierarchy Process (AHP) (Tanjung \& Devi, 2013). The ANP method can improve the deficiencies of the AHP method whereby its ability can accommodate linkages between criteria or between alternatives (Saaty, 2005; Saaty \& Vargas, 2006). The linkage between criteria on the ANP method has two types: First, relation in a set of elements (inner dependence); and; Second, interrelation between different elements (outer dependence). Stages of decision-making with ANP are as follows (Legendre, 2005; Chung et al., 2005): (1) develop problem structure and develop the linkage model; (2) forming a pairwise comparison matrices; (3) calculating element weight; (4) geometric mean ; (5) rater agreement and (6) creating supermatrix.

\section{Result and Discussion}

In studying the economic potential in Maluku Province, identification and analysis of potential economic categories or subcategories in Maluku Province use 4 (four) kinds of analysis tools, i.e. location quotient (LQ), growth ratio model (MRP), Overlay and ANP. In more detail, the discussion through the four analytical tools will be described as follow.

Location Quotient (LQ) analysis tools are used to identify the comparative advantages of economic activity in Province by comparing it to the national (Adhitama, 2012; Sepono P., 1993). According to Adisasmita (2005), base activity has a role as the prime mover in the growth of a region. The higher the exports of one region to another will be the more advanced the region grows, and vice versa. Any changes in the base sector will have a multiplier effect on the regional economy.

The LQ analysis in Table 2 shows that Maluku Province has 8 (eight) economic base categories with comparative advantage $(\mathrm{LQ}>1)$; agriculture, forestry and fishery; water supply, waste management and recycling; major trade and retail and auto-motorcycle repair; transportation and warehousing; government administration, defense and compulsory social 
security schemes; education services; health services and social activities; and other service. Meanwhile, although other sectors are not a base but can not ignore because it could be with the help of the base sector, it can help the development of non-base sector into a new base sector.

Table 2. Location Quotient ( LQ) Maluku Province Year 2010 - 2016

\begin{tabular}{|c|c|c|c|c|c|c|c|c|c|c|}
\hline & \multirow{2}{*}{ Industrial Origin } & \multicolumn{7}{|c|}{ Location Quotient (LQ) } & \multirow{2}{*}{ Average } & \multirow{2}{*}{ Result } \\
\hline & & 2010 & 2011 & 2012 & 2013 & 2014 & 2015 & 2016 & & \\
\hline A & $\begin{array}{l}\text { Agriculture, Livestock, } \\
\text { Forestry and Fishery }\end{array}$ & 1.83 & 1.82 & 1.83 & 1.83 & 1.83 & 1.76 & 1.73 & 1.80 & Base \\
\hline B & Mining and Quarrying & 0.29 & 0.32 & 0.31 & 0.31 & 0.36 & 0.38 & 0.39 & 0.34 & $\begin{array}{l}\text { Non } \\
\text { Base }\end{array}$ \\
\hline $\mathrm{C}$ & Manufacturing Industry & 0.24 & 0.24 & 0.24 & 0.24 & 0.25 & 0.24 & 0.24 & 0.24 & $\begin{array}{l}\text { Non } \\
\text { Base }\end{array}$ \\
\hline $\mathrm{D}$ & $\begin{array}{l}\text { Electricity, Gas \& Water } \\
\text { Supply }\end{array}$ & 0.08 & 0.08 & 0.08 & 0.08 & 0.09 & 0.09 & 0.09 & 0.08 & $\begin{array}{l}\text { Non } \\
\text { Base }\end{array}$ \\
\hline$E$ & $\begin{array}{l}\text { Water Supply, Waste } \\
\text { Management and Recycling }\end{array}$ & 6.22 & 6.21 & 6.2 & 6.18 & 6.08 & 5.64 & 6.01 & 6.08 & Base \\
\hline $\mathrm{F}$ & Construction & 0.69 & 0.7 & 0.69 & 0.7 & 0.7 & 0.68 & 0.69 & 0.69 & $\begin{array}{l}\text { Non } \\
\text { Base }\end{array}$ \\
\hline G & $\begin{array}{l}\text { Wholesales, Retail, Car } \\
\text { Repair, Motor }\end{array}$ & 1 & 0.98 & 1 & 1.03 & 1 & 1.03 & 1.05 & 1.01 & Base \\
\hline $\mathrm{H}$ & $\begin{array}{l}\text { Transportation and } \\
\text { Warehousing }\end{array}$ & 1.46 & 1.44 & 1.41 & 1.41 & 1.4 & 1.35 & 1.32 & 1.40 & Base \\
\hline 1 & $\begin{array}{l}\text { Provision of Accommodation } \\
\text { and Meals Drink }\end{array}$ & 0.59 & 0.59 & 0.59 & 0.6 & 0.58 & 0.59 & 0.57 & 0.59 & $\begin{array}{l}\text { Non } \\
\text { Base }\end{array}$ \\
\hline$J$ & $\begin{array}{l}\text { Information and } \\
\text { Communication }\end{array}$ & 0.94 & 0.92 & 0.87 & 0.86 & 0.83 & 0.81 & 0.82 & 0.86 & $\begin{array}{l}\text { Non } \\
\text { Base }\end{array}$ \\
\hline $\mathrm{K}$ & $\begin{array}{l}\text { Financial Services and } \\
\text { Insurance }\end{array}$ & 0.86 & 0.96 & 0.95 & 0.95 & 0.96 & 0.93 & 0.94 & 0.94 & $\begin{array}{l}\text { Non } \\
\text { Base }\end{array}$ \\
\hline $\mathrm{L}$ & Real Estate & 0.13 & 0.13 & 0.12 & 0.12 & 0.12 & 0.11 & 0.12 & 0.12 & $\begin{array}{l}\text { Non } \\
\text { Base }\end{array}$ \\
\hline $\mathrm{M}, \mathrm{N}$ & Company Services & 0.74 & 0.72 & 0.7 & 0.68 & 0.64 & 0.61 & 0.59 & 0.67 & $\begin{array}{l}\text { Non } \\
\text { Base }\end{array}$ \\
\hline $\mathrm{O}$ & $\begin{array}{l}\text { Mandatory Administration } \\
\text { of Government, Defense and } \\
\text { Social Security }\end{array}$ & 4.82 & 4.96 & 5.25 & 5.33 & 5.4 & 5.6 & 5.71 & 5.30 & Base \\
\hline$P$ & Educational Services & 1.91 & 1.84 & 1.74 & 1.67 & 1.71 & 1.69 & 1.68 & 1.75 & Base \\
\hline Q & $\begin{array}{l}\text { Health Services and Social } \\
\text { Activities }\end{array}$ & 2.46 & 2.38 & 2.31 & 2.14 & 2.01 & 1.94 & 1.87 & 2.16 & Base \\
\hline $\begin{array}{l}\mathrm{R}, \mathrm{S} \\
\mathrm{T}, \mathrm{U}\end{array}$ & Other Services & 1.36 & 1.26 & 1.2 & 1.13 & 1.08 & 1.03 & 0.99 & 1.15 & Base \\
\hline
\end{tabular}

Source: data processing 
Table 2 shows that the sector of water supply, waste management, waste, and recycling is an economic sector that has the highest average of 6.08. This data indicates that the sector has a reasonably good economic role, where the region can meet its own needs within its territory (Marlina, 2014). Besides, this sector has the potential to be exported out of the region, the minimum being export to the nearest area (Aswandi \& Kuncoro, 2002; Setyorini \& Gunawan, 2008).

Meanwhile, the advantages of the agricultural sector are mainly due to the enormous contribution of the fisheries sub-sector to 65 percent of the total sector (Latuny, 2014). Forward linkage and backward linkages that are expertly arranged will have a positive effect on increasing the output of other sectors that have an attachment in terms of input-output, which in turn increases the region's revenue. Maluku province as the most abundant fish producer with the best quality encourages the central government to determine this area as a national fish barn.

However, in another side, the agricultural sector, forestry and fishery category, the value of its LQ has a decreased trend. This condition is due to the fishery moratorium resulting in a decrease in the fishery subcategory; the forest sub-category's decrease in illegal logging activities from strict supervision by the government and the security apparatus tends to decrease production. From 2010 to 2016, for the last few years (2013-2014) the El-Nino effect was the cause of prolonged drought resulting in crop failures for food crops and horticulture commodities in districts central to agriculture in Maluku Province, thus indirectly decreasing production in this sub-category. The existence of "Gunung Botak" phenomenon in 20132014 created much agricultural land in the Buru regency to become useless as agricultural workers become a gold miner in the "Gunung Botak" area. Besides, the slowing growth of the agricultural sector suspect as an implication of the discovery of a gold mine on Buru Island, which design as a Moluccan Rice Granary, which caused a decrease in rice productivity in the rice production center. The conduct of gold mining by the people of Buru caused many farmers to become miners and have an impact on the decline in rice production in the area.

The growth-ratio model (MRP) is an analytical tool to identify potential economic categories based on growth criteria (Yusuf, 1999). MRP analysis consists of two measurement instruments, i.e., the ratio of growth in the study area (RPs) which shows the growth ratio between the research area and the larger reference area; Maluku Province to the national area. The second instrument is the ratio of growth in the reference area (RPr).

Table 3 shows that the RPs of agriculture, forestry and fishery categories in Maluku Province are less than 1 . This data indicates that the categories of agriculture, forestry, and fisheries are not potential economic activities in Maluku Province based on the growth criteria. Meanwhile, for the national level, the category of agriculture, forestry, and fisheries is also not a potential category because it has a less than $1 \mathrm{RPr}$ value.

The mining and quarrying category in Maluku Province has an RP value of more than 1 , making it is a potential category based on the growth criteria. Different conditions are seen at the National level since the RPr value of mining and quarrying shows less than 1 . The overall growth of mining and quarrying categories in Indonesia are less potential. But in Maluku 
Province, it is a potential category based on the growth criteria. Thus the overall mining and quarrying category in Indonesia is less potential in terms of growth. But in Maluku Province, this category is a potential category based on its growth criteria. This result indicates that these sectors are sectors that have commodities with high economic value so that if regulated and managed efficiently and effectively it will have a more significant positive impact on the sector, as well as sectors that have relevance, both forward and backward linkages in terms of products produced, which in turn increases the region's revenue in Maluku Province. These findings are identical with research in Rembang District which shows that a competitive and surplus economic sector is the mining and quarrying sector (Gunawan, 2011).

Table 3. Maluku Province Growth Ratio (RPs) and Indonesia Growth Ratio in Maluku Province (RPr) 2010 - 2016

\begin{tabular}{|c|c|c|c|c|c|}
\hline & \multirow{2}{*}{ Industrial Origin } & \multicolumn{2}{|c|}{ RPs } & \multicolumn{2}{|c|}{ RPr } \\
\hline & & Real & Nominal & Real & Nominal \\
\hline A & Agriculture, Livestock, Forestry and Fishery & 0.95 & - & 0.81 & - \\
\hline $\mathrm{B}$ & Mining and Quarrying & 7.59 & + & 0.23 & - \\
\hline $\mathrm{C}$ & Manufacturing Industry & 1.21 & + & 0.97 & - \\
\hline $\mathrm{D}$ & Electricity, Gas \& Water Supply & 2.14 & + & 1.07 & + \\
\hline $\mathrm{E}$ & Water Supply, Waste Management and Recycling & 0.76 & - & 0.94 & - \\
\hline $\mathrm{F}$ & Construction & 1.11 & + & 1.4 & + \\
\hline G & Wholesales, Retail, Car Repair, Motor & 1.36 & + & 1.06 & + \\
\hline $\mathrm{H}$ & Transportation and Warehousing & 0.92 & - & 1.45 & + \\
\hline 1 & Provision of Accommodation and Meals Drink & 1.21 & + & 1.19 & + \\
\hline$J$ & Information and Communication & 0.78 & - & 2.22 & + \\
\hline $\mathrm{K}$ & Financial Services and Insurance & 1.45 & + & 1.54 & + \\
\hline $\mathrm{L}$ & Real Estate & 0.67 & - & 1.23 & + \\
\hline $\mathrm{M}, \mathrm{N}$ & Company Services & 0.62 & - & 1.7 & + \\
\hline $\mathrm{O}$ & $\begin{array}{l}\text { Mandatory Administration of Government, Defense and } \\
\text { Social Security }\end{array}$ & 2.3 & + & 0.7 & - \\
\hline$P$ & Educational Services & 0.77 & - & 1.4 & + \\
\hline Q & Health Services and Social Activities & 0.49 & - & 1.62 & + \\
\hline $\begin{array}{l}\mathrm{R}, \mathrm{S} \\
\mathrm{T}, \mathrm{U}\end{array}$ & Other Services & 0.34 & - & 1.49 & + \\
\hline
\end{tabular}

Source: data processing

Meanwhile, the category of processing industry is potential in Maluku Province with RPs value of more than $1(\mathrm{RPs}=1.21)$, but the National RPr shows the category of processing industry is still less potential because $\mathrm{RPr}$ value is less than $1(\mathrm{RPr}=0.97)$. Afterward, the category of electricity and gas procurement is a potential category in Maluku Province with RPs calculation of more than $1(\mathrm{RPs}=2.14)$. This category is also a potential category in 
general in Indonesia, as the RPr value is 1.07 . Based on the subcategories, electricity is dominant and potential shown by its more significant than 1 . Meanwhile, the water supply, waste management, waste, and recycling category in Maluku Province is less potential (RPs = 0.76) in growth, with an $R \operatorname{Pr}$ value of 0.94 at the national level.

The category of construction in Maluku Province is a very potential category (RPs = 1.11) for growth, as well as the growth of the construction category in Indonesia is also a potential category with an RPr value of 1.40. Major trade and retail and auto-motorcycle repair category are also potential in Maluku Province with RPs value are 1.36. Furthermore, the category of transportation and warehousing in Maluku Province is less potential with an RPs value of 0.92 , while nationally it is very potential with an $R \operatorname{Pr}$ of 1.45 .

Table 4 Analysis of Maluku Province Economic Potential Overlay 2010-2016

\begin{tabular}{|c|c|c|c|c|c|c|c|}
\hline & Industrial Origin & RPs & RPr & LQ & \multicolumn{3}{|c|}{ Overlay } \\
\hline A & Agriculture, Livestock, Forestry and Fishery & 0.95 & 0.81 & 1.8 & - & - & + \\
\hline B & Mining and Quarrying & 7.59 & 0.23 & 0.34 & + & - & - \\
\hline C & Manufacturing Industry & 1.21 & 0.97 & 0.24 & + & - & - \\
\hline $\mathrm{D}$ & Electricity, Gas \& Water Supply & 2.14 & 1.07 & 0.08 & + & + & - \\
\hline $\mathrm{E}$ & Water Supply, Waste Management and Recycling & 0.76 & 0.94 & 6.08 & - & - & + \\
\hline $\mathrm{F}$ & Construction & 1.11 & 1.4 & 0.69 & + & + & - \\
\hline G & Wholesales, Retail, Car Repair, Motor & 1.36 & 1.06 & 1.01 & + & + & + \\
\hline $\mathrm{H}$ & Transportation and Warehousing & 0.92 & 1.45 & 1.4 & - & + & + \\
\hline I & Provision of Accommodation and Meals Drink & 1.21 & 1.19 & 0.59 & + & + & - \\
\hline J & Information and Communication & 0.78 & 2.22 & 0.86 & - & + & - \\
\hline $\mathrm{K}$ & Financial Services and Insurance & 1.45 & 1.54 & 0.94 & + & + & - \\
\hline L & Real Estate & 0.67 & 1.23 & 0.12 & - & + & - \\
\hline $\mathrm{M}, \mathrm{N}$ & Company Services & 0.62 & 1.7 & 0.67 & - & + & - \\
\hline $\mathrm{O}$ & $\begin{array}{l}\text { Mandatory Administration of Government, Defense and } \\
\text { Social Security }\end{array}$ & 2.3 & 0.7 & 5.3 & + & - & + \\
\hline $\mathrm{P}$ & Educational Services & 0.77 & 1.4 & 1.75 & - & + & + \\
\hline Q & Health Services and Social Activities & 0.49 & 1.62 & 2.16 & - & + & + \\
\hline $\begin{array}{l}\mathrm{R}, \mathrm{S}, \\
\mathrm{T}, \mathrm{U}\end{array}$ & Other Services & 0.34 & 1.49 & 1.15 & - & + & + \\
\hline
\end{tabular}

Source: data processing

The category of accommodation and food and beverage in Maluku Province is a potential category $(\mathrm{RPs}=1.21)$. At the National level, this category is also a possible category with an RPr equal to 1.19. Information and communication in Maluku Province is less potential with an RPs value of 0.78 ; while at the national level it is a very potential category with an RPr value of 2.12. Real estate is less potential in Maluku Province (RPs = 0.67). while at the National Level it is potential shown by an $\mathrm{RPr}$ value of $\mathrm{RPr}=1.23$. Corporate 
services in Maluku Province is not so potential (RPs=0.62). While the national level show, it is very potential $(\mathrm{RPr}=1.70)$. Government administration, defense and compulsory social security schemes in Maluku Province is very potential shown with an RPs value of 2.30; at the national level this category less potential with an $R P r$ value of 0.70 . Education services; categories of health services and social activities; and other service categories in Maluku Province, it is less potential, shown from an RPs value of $0.77 ; 0.49$ and 0.34 respectively. On the contrary, the national level show those categories are potential, with an RPr value of 1.40 for the education service categories; 1.62 for the category of health services and social activities and other service categories is 1.49 .

Overlay views potential economic categories and subcategories regarding contributions and PDRB growth. If the LQ and MRP analysis results are overlay, there are four possibilities regarding the economic sector of the research area. First, if $L Q>1$ and $R P s>R P r$ (for RPs and RPRs greater than 1), then the sector is a very dominant sector, either from the contribution or its growth (Basuki \& Gayatri, 2009; Ariyasa, 2009).

The sector is an advanced and fast-growing sector and can view as a leading sector in the studied province. Secondly, if LQ $<1$ but RPs $>\mathrm{RPr}$ (for RPs and RPRs greater than 1) then the sector has a small contribution but its growth is getting bigger. This sector is a growing sector, and its contribution can be increased to become the dominant sector. This sector can view as a potential sector in the studies province. Third, if $L Q>1$, but $\mathrm{RPs}<\mathrm{RPr}$; then the sector has a significant contribution, but its growth is smaller. This sector is a sector that is experiencing a decline in growth. This sector can view as a depressed sector in the studied province. Fourth, if $\mathrm{LQ}<1$ and $\mathrm{RPs}<\mathrm{RPr}$ then the sector is not potential both from the criteria of contribution and growth criteria. This sector lags in the studied province.

In order to determine the economic potential in Maluku Province more comprehensively, the overlay is done to see the benefits and economic potential in Maluku Province. It is integration between LQ (comparative advantage aspect) and MRP analysis (the ratio of growth in the study area - RPs). The results of the Overlay calculation year 2010 - 2016 in Table 4 shows the economic sector in Maluku Province, both growth and contribution are classified as follows: First, growth $(+)$ and contribution $(+)$ are in the sectors of government administration, defense, mandatory social security schemes, and significant trade and retail; car and motorcycle repairs. The sector shows a very dominant activity both from growth and the substantial contribution to PDRB and development in Maluku Province. The great potential of these categories because of the various analytical tools used shows that this economic category has comparative advantages, competitive advantages, specialization while having a good growth ratio when compared to the national economy.

Second, growth (+) and contribution (-), are in the mining and quarrying sectors, the processing industry, the procurement of electricity and gas, construction, the accommodation and food, and beverage and financial services, and insurance. It indicates an activity that is predominantly growing but contributes little. This activity needs to increase its contribution to become a dominant activity. Third, growth (-) and contribution (+), are found in agriculture, forestry and fisheries, water supply, waste management, waste and recycling, transportation and warehousing, education services, health services, and social activities and other services. 
Those indicate activity with a small growth but significant contribution. This activity may be decreasing. Fourth, growth (-) and contribution (-), in the information and communications sector, enterprise services, and real estate indicate an activity that is not potential either of the growth or contribution criteria.

The Analytic Network Process (ANP) approach is the right choice in carrying out this study enabling developmental policy formulation of the Maluku Province but faces the following constraints (Saaty, 2008). The presence of variables difficult to quantify or cannot quantify, such as (1) the behavior of actors; (2) the existence of values of subjective variables from consensus judgment; (3) secondary and primary data limitations. Also, the interrelated complexity of these factors requires a comprehensive and holistic understanding to avoid logical errors in the conclusion or decision.

There were 14 expert respondents in the questionnaire selected by considering the participant's understanding of the problem. Therefore, the technique of selecting expert respondents is purposive sampling based on expertise or judgment sampling. In this case, the experts selected are those with knowledge, competencies; disciplines; and/or sufficient experience, related to the development of the region and the maritime competitiveness in Maluku Province.

The goal through the ANP approach was the development in the Maluku province, while policy concerns for the regional development can divide into four aspects: strengths, opportunities, weaknesses, and threats. Various indicators and explanation shows in Table A and $\mathrm{B}$ in the appendix.

Figure 1. SWOT- Analytic Network Process (ANP) of Regional Development in Maluku Province

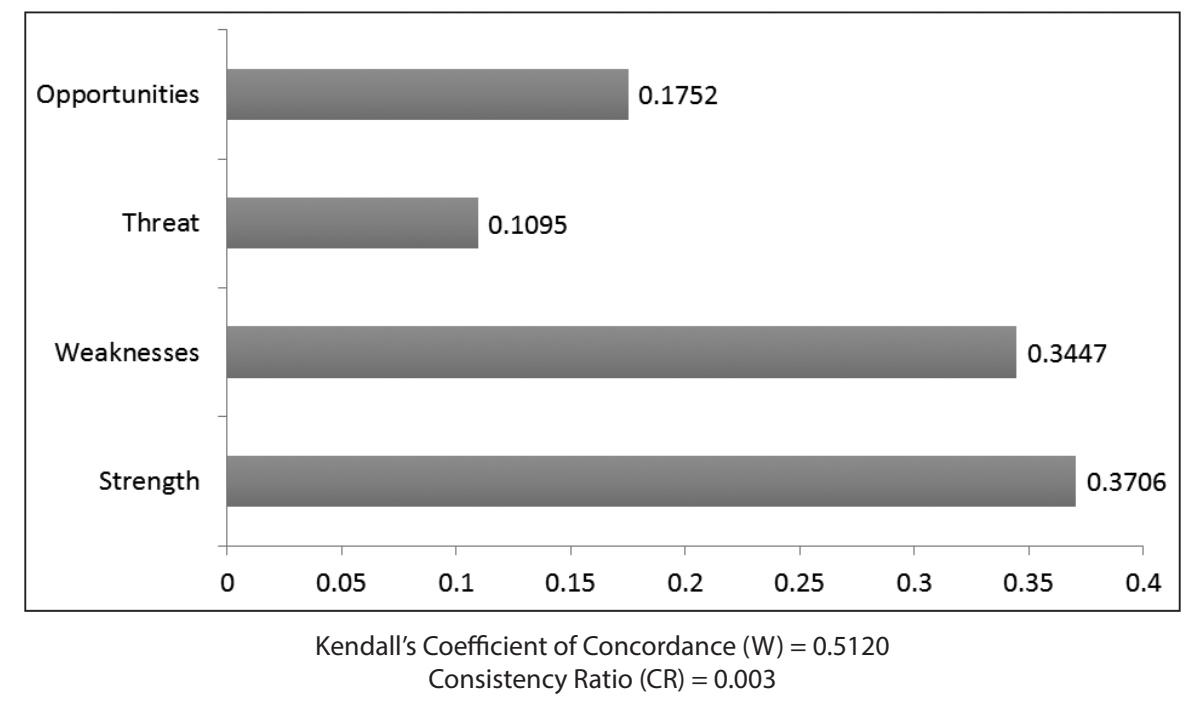

The SWOT-ANP analysis in Figure 1 shows that the dominating factor on the development in Maluku Province is the strengths, which reached $37.06 \%$ with a value of Kendall's coefficient of concordance or rater agreement amounting to 0.5120. Thus, formulating policies on the development in Maluku Province can be based on factors that 
maximize the strengths and opportunities that can simultaneously minimize the weaknesses and threats. Meanwhile, the most influential policy on the development of the Maluku Province is the accelerated development of infrastructure by 18 percent with a fairly high level of compliance (Kendall's coefficient of concordance ) of 0.8370 . this indicates that the level of agreement or the conformity of opinion of the respondents is big giving high confidence, whereas if the opinion of the respondents has a lower level of conformity value, then the respondent's answers are more varied. Moreover, the consistency ratio shows that each priority value shows consistent results (below 10 percent).

The acceleration of infrastructure development becoming a priority policy for the development in Maluku Province is the right decision, considering that Maluku province consists of many islands. Thus, policies through the acceleration of infrastructure are essential for connectivity and fisheries and marine development as well as tourism as the main sectors. Therefore, the acceleration of infrastructure development should take precedence, ranging from the construction of road infrastructure, bridges, ports, to the airport. The more connected the areas in Maluku Province, the cheaper and easier the mobility of goods and/or people, including transaction costs.

The findings are in line with previous research which states that Maluku Province, which is geographically an archipelago consisting of many islands, has naturally formed a long range of control that requires attention and policy in the context of creating an integrated regional unity. Thus the development process can run well. In supporting the acceleration of regional development in Maluku Province, the availability of infrastructure is needed to stimulate and support development activities, both social and economic development so that the welfare of society in the future can maximized (Kalalimbong, 2010).

Table 5. Policy Priorities of Regional Development in Maluku Province

\begin{tabular}{lc}
\hline Alternatives & Ranking \\
\hline Increased Investment and Regional Development & 9 \\
Bureaucracy Reform & 7 \\
Destinations of Marine Tourism & 5 \\
Acceleration of Infrastructure Development & $\mathbf{1}$ \\
Increased Availability of Various Foodstuffs & 4 \\
Increased Capacity or Electricity Supply & 11 \\
Improved Access to Education and Health & 3 \\
Poverty Alleviation & 2 \\
Program Synchronization & 12 \\
Regional Innovations & 8 \\
Rural Economic Development & 10 \\
Spatial Planning and Accelerated Development of Underdeveloped Regions & 6 \\
\hline
\end{tabular}

Source: Based on The Analytic Network Process (ANP) 
Maluku Province is an archipelago cluster located in the eastern part of Indonesia. As is typical of the archipelago, more than $90 \%$ of the two provinces consist of waters, only a small portion of the land of the total area, and not all islands inhabited by the inhabitants (BPS, 2016). The spread of inter-island locations that spread leads to lower access between island clusters, so that the range of control becomes more far-reaching and becomes a separate physical challenge for infrastructure development. Therefore, the quality and quantity of adequate infrastructure will have a positive impact as a source of sustainable economic growth (See Table 5).

\section{Conclusion}

There are several findings from this study. First, this study found strong evidence that the Maluku Province have 8 categories of economic sector that has the base categories. This categories includes agriculture, forestry and fisheries; water supply, waste management and recycling; major trade and retail and auto-motorcycle repair; transportation and warehousing; government administration, defense and compulsory social security schemes; education services; health services and social activities; and other service categories. The growth-ratio model (MRP) shows that the sector with the highest average the ratio of growth in the study area (RPs) in Maluku province is the mining and quarrying sector.

Furthermore, the overlay analysis indicates that the administrative sectors of government, defense, compulsory social security schemes, and major trade and retail; car and motorcycle repairs are the most dominant activities both of growth and the tremendous contribution to PDRB and development in Maluku Province. Second, the analysis of SWOT-ANP showed that the most influential factor on the development in Maluku Province is the strengths, namely economic growth, high rate of growth of SMEs, the availability of water resources, biophysical condition and the presence of land, marine, and bastion of Indonesia and national fish resource. Therefore, formulating development policies in Maluku can be based on factors that can maximize the strength and opportunities and simultaneously minimize the weaknesses and threats. The most prioritized developmental policy in Maluku Province is the acceleration of infrastructure development. Thus, policies through the acceleration of infrastructure are essential for connectivity and fisheries and marine development as well as tourism as the main sectors.

The policy implication that can do is to strengthen the implementation of Nawacita program primarily on the main element that is building connectivity in Maluku province. Integrated connectivity development between the growth centers in the economic corridor and also between the economic corridors. Local governments need to improve and develop integrated inter-regional infrastructure in Maluku areas. Road construction needs to take into account the ecological balance of the area and take into consideration the benefits to be gained by the local community. In road construction is expected to use local labor or local community. Finally, the government needs to make efforts in increasing investment, especially in infrastructure, through cooperation with the central government, other local government, state-owned and local enterprises, the private and public sector. 


\section{Acknowledgments}

This research supported by Maluku Corner Center of Excellence, Universitas Padjadjaran (UNPAD). We thank our colleagues from Department of Economics, Maluku Corner Center of Excellence Universitas Padjadjaran who provided insight and expertise that greatly assisted the research and we thank to "anonymous" reviewers for their so-called insights.

\section{References}

Adhitama, R. (2012). Pengembangan Sektor-Sektor Ekonomi di Tiap Kecamatan di Kabupaten Magelang (Development of Economic Sectors in Each District in Magelang District). Economics Development Analysis Journal, 1(2), 1-9.

Adisasmita, R. (2005). Dasar-Dasar Ekonomi Wilayah (The Fundamental of RegionalEconomic). Yogyakarta: Graha Ilmu.

Ariyasa, I. B. W. (2009). Identifikasi Sektor atau Subsektor Potensial untuk Menentukan Prioritas Pembangunan di Kabupaten Gianyar Provinsi Bali (Sector Identification or Potential Subsector to Determine Development Priorities in Gianyar Regency, Bali Province). Denpasar: Universitas Udayana.

Arsic, S., Mihajlovic, I. N., \& Fedajev, A. (2018). Approach Within ANP-SWOT Framework for Prioritization of Ecosystem Management and Case Study of National Park Djerdap, Serbia. Ecological Economics Journal, 146, 85-95. https://doi.org/10.1016/j. ecolecon.2017.10.006

Arsyad, L. (1999). Pengantar Perencanaan dan Pembangunan Ekonomi Daerah (Introduction to Regional Economic Planning and Development). Yogyakarta: BPFE UGM.

Aswandi, H., \& Kuncoro, M. (2002). Evaluasi Penetapan Kawasan Andalan : Studi Empiris di Kalimatan Selatan 1993-1999 (Evaluation of Mainstay Area Determination: Empirical Study in South Kalimantan 1993-1999). Jurnal Ekonomi Dan Bisnis, 17(1), 27-45.

Azimi, R., Yazdani-Chamzini, A., Fouladgar, M. M., Zavadskas, E. K., \& Basiri, M. H. (2011). Ranking the Strategies of Mining Sector Through ANP and TOPSIS in a SWOT Framework. Journal of Business Economics and Management, 12(4), 670-689.

Basuki, T. A., \& Gayatri, U. (2009). Penentuan Sektor Unggulan dalam Pembangunan Daerah : Studi kasus di Kabupaten Ogan Komering Ilir (Determination of Leading Sectors in Regional Development: Case study in Ogan Komering Ilir Regency). Jurnal Ekonomi Dan Studi Pembangunan, 10(1), 34-50.

Bendavid-Val, A. (1991). Regional and Local Economic Analysis for Practitioner (Fourth). California: Sage Publication.

Chung, S. H., Lee, A. H. L., \& Pearn, W. L. (2005). Analytic Network Process (ANP) Approach For Product Mix Planning in Semiconductor Fabricator. International Journal of Production Economics, 96(1), 15-36.

Gunawan, M. W. (2011). No TitleAnalisis Sektor-Sektor Unggulan Perekonomian Kabupaten Rembang tahun 2000-2008 (Analysis of the Leading Sectors of the Rembang Regency Economy in 2000-2008). (Unpublished Thesis). Bogor: Institut Pertanian Bogor. 
Kalalimbong, A. (2010). Kajian Infrastruktur di Provinsi Maluku (Infrastructure Study in Maluku Province). Jurnal Teknologi, 7(1), 751-758.

Kuncoro, M. (2004). Otonomi dan Pembangunan Daerah (Autonomy and Regional Development). Jakarta: Erlangga.

Latuny, E. M. (2014). Analisis Sektor Unggulan di Provinsi Maluku (Leading Sector Analysis in Maluku Province). Jurnal Cita Ekonomika, 8(2), 148-157.

Legendre, P. (2005). Species Associations: The Kendall Coefficient of Concordance Revisited. Society Journal of Agricultural, Biological, and Environmental Statistics, 10(2), 226-245.

Marlina, Y. (2014). Analisis Sektor Unggulan Dalam Perekonomian Kota Bogor 2006-2012 (Leading Sector Analysis in the Economy of Bogor City 2006-2012). (Unpublished Thesis). Bogor: Institut Pertanian Bogor.

Saaty, T. L. (2005). Theory and Applications of the Analytic Network Process: Decision Making with Benefits, Opportunities, Costs, and Risks. Pittsburgh: RWS Publications.

Saaty, T. L. (2008). Decision Making With The Analytic Hierarchy Process. International Journal Services Sciences, 1(1), 83-98.

Saaty, T. L., \& Vargas, L. G. (2006). Decision Making with the Analytic Network Process: Economic, Political, Social and Technological Applications with Benefits, Opportunities, Costs, and Risks (2nd editio). Pittsburgh: Springer.

Setyorini, G. D., \& Gunawan, R. S. (2008). Identifikasi Pengembangan Wilayah Kabupaten Anggota Lembaga Regional Barlingmascakeb (Identification of Regional Development of Regency Members of the Barlingmascakeb Regional Institution). Jurnal Ekonomi Dan Studi Pembangunan, 9(1), 26-43.

Tanjung, H., \& Devi, A. (2013). Metodologi Penelitian Ekonomi Islam (Islamic Economic Research Methodology). Bekasi: Gramata Publishing.

Tarigan, R. (2005). Ekonomi Regional: Teori dan Aplikasi (Regional Economics: Theory and Applications). Jakarta: Bumi Aksara.

Yüksel, I., \& Dagdeviren, M. (2007). Using The Analytic Network Process (ANP) in A SWOT Analysis: A Case Study For A Textile Firm. Information Sciences, 177(16), 3364-3382.

Yusuf, M. (1999). Model Rasio Pertumbuhan (MRP) sebagai Salah Satu Alat Analisis Alternatif dalam Perencanaan Wilayah dan Kota: Aplikasi Model Wilayah BangkaBelitung (Growth Ratio Model (MRP) as One Alternative Analysis Tool in Urban and Regional Planning: Bangka-Belitung. Ekonomi Dan Keuangan Indonesia, XLVII(2), 219-233. 


\section{Appendix}

Table A. SWOT Analysis of Regional Development in Maluku Province

\begin{tabular}{|c|c|c|}
\hline No & Indicators & Explanations \\
\hline \multicolumn{3}{|r|}{ Strength } \\
\hline 1 & Economic Growth & Economic growth above the national average \\
\hline 2 & SME's Growth & $\begin{array}{l}\text { The high rate of SME growth is indicated by the significant increase in the } \\
\text { number of cooperatives and businesses between years }\end{array}$ \\
\hline 3 & Aquatic Resources & $\begin{array}{l}\text { The availability of abundant marine resources, especially for marine fishery } \\
\text { aspect, as well as islands group as a source of maritime wealth which is not } \\
\text { owned by other provinces }\end{array}$ \\
\hline 4 & $\begin{array}{l}\text { Biophysical Conditions and } \\
\text { Land }\end{array}$ & $\begin{array}{l}\text { Biophysical conditions and the existence of land that can support the } \\
\text { development of palawija agriculture, plantations (spices), livestock (local } \\
\text { ruminants) and mining (minerals, oil and gas). }\end{array}$ \\
\hline 5 & Marine Tourism & $\begin{array}{l}\text { The tendency of increasing interest of tourists, both local and international } \\
\text { to marine tourism in Maluku province. }\end{array}$ \\
\hline 6 & $\begin{array}{l}\text { NKRI Defense Fort and } \\
\text { National Fish Granary }\end{array}$ & $\begin{array}{l}\text { One more characteristic is that almost the islands are border areas, except } \\
\text { the islands of bangka-belitung and have the advantage as a fortress of NKRI } \\
\text { and national fish granaries }\end{array}$ \\
\hline
\end{tabular}

\section{Weaknesses}

1 Access Between Clusters and Span of Control

2 Beach Abrasion

3 Infrastructure

$4 \quad$ Agricultural Productivity

5 Processing and Cultivation of Fisheries

6 Space Utilization

$7 \quad$ Environmental Carrying Capacity

8 Allocation of Bank Credit

9 Legal Certainty Related To Land

10 The Quality of Human Resources

11 Public Services
The existence of the archipelagic cluster area also resulted in low access between clusters and control ranges.

The appearance of coastal abrasion

The availability of infrastructure, both in quality and quantity, is still low (roads, major ports and airports), as well as the availability of insufficient and uneven supply of electricity that impacts on sustainable sources of economic growth.

The agricultural sector which is the focus of most of the working population in Maluku has low productivity levels and has not been able to improve the welfare of society in general

The fishery sector is still limited to capture fisheries without the processing of fishery products, and the absence of export ports to export superior commodities

Utilization of space is still not optimal and there are many many areas left behind

The carrying capacity and capacity of the environment in Maluku is quite alarming

The allocation of bank credit has not yet been channeled, used and identified optimally into the productive sector.

The problem of the absence of legal certainty, whether customary in relation to land in some areas as well as with investments that become obstacles for large investors.

The quality of human resources is still low, particularly related to the development of oil and gas blocks in order to encourage economic growth in Maluku Province. In this regard, Maluku is still among the top 10 provinces in the national $\mathrm{HDI}$ achievement.

Low public services, the stabilization of democracy, security and public order and the quality of peace. 


\begin{tabular}{|c|c|c|}
\hline \multicolumn{3}{|r|}{ Threat } \\
\hline 1 & Supply of Electrical Energy & The availability of electricity supply is still low \\
\hline 2 & Imported Goods & $\begin{array}{l}\text { Negative net exports indicate the fragility of goods entering Maluku } \\
\text { province that could kill local production }\end{array}$ \\
\hline 3 & $\begin{array}{l}\text { ASEAN Economic } \\
\text { Community (MEA) }\end{array}$ & $\begin{array}{l}\text { ASEAN Economic Community Policy potentially threatens industrial and } \\
\text { labor competitiveness in Maluku }\end{array}$ \\
\hline 4 & Regional Investment & Investor perceptions of the investment climate in Maluku are still low \\
\hline 5 & Ecological Vulnerability & $\begin{array}{l}\text { The ecological vulnerability of small islands can affect the development of } \\
\text { small islands in Maluku Province }\end{array}$ \\
\hline \multicolumn{3}{|r|}{ Opportunities } \\
\hline 1 & $\begin{array}{l}\text { Alignment to Eastern } \\
\text { Indonesia }\end{array}$ & $\begin{array}{l}\text { The high commitment of the central government to improve economic } \\
\text { growth especially with the development of infrastructure in the Eastern } \\
\text { Region. This is reflected in the accelerated development of transportation } \\
\text { and energy facilities that can support regional economic activity }\end{array}$ \\
\hline 2 & $\begin{array}{l}\text { Allocation of Village Funds } \\
\text { (Alokasi Dana Desa) }\end{array}$ & $\begin{array}{l}\text { The existence of village fund allocation policy from the central government } \\
\text { has the potential to encourage regional growth, especially in rural areas }\end{array}$ \\
\hline 3 & Potential Food & $\begin{array}{l}\text { Sago agricultural commodities can be an option. Indeed, the current } \\
\text { consumption of sago has diminished, but this is the identity of the } \\
\text { Moluccas. Thus, sago can be used for the fulfillment of food consumption } \\
\text { or for industry, including for other food commodities. }\end{array}$ \\
\hline 4 & Tourism Program & $\begin{array}{l}\text { Central and local government regulation is still open for tourism \& trade } \\
\text { sector and central government policy to eastern Indonesia. In addition, } \\
\text { island clusters can be a center of growth }\end{array}$ \\
\hline 5 & $\begin{array}{l}\text { Foreign and Domestic } \\
\text { Investment in Oil and Gas }\end{array}$ & $\begin{array}{l}\text { Maluku Province has potential for foreign and domestic investments, } \\
\text { particularly on oil and gas }\end{array}$ \\
\hline
\end{tabular}

Table B. Policy Alternatives of Regional Development in Maluku Province

\begin{tabular}{ll}
\hline \multicolumn{1}{c}{ Policy Alternatives } \\
\hline 1. Increased Capacity or Electricity Supply \\
2. Program Synchronization \\
3. Acceleration of Infrastructure Development \\
4. Rural Economic Development \\
5. Regional Innovations \\
6. Bureaucracy Reform \\
7. Spatial Planning and Accelerated Development of Underdeveloped Regions \\
8. Increased Availability of Various Foodstuffs \\
9. Poverty Alleviation \\
10. Improved Access to Education and Health \\
11. Destinations of Marine Tourism \\
12. Increased Investment and Regional Development \\
\hline
\end{tabular}

